\title{
Morphological variation in Kersting's groundnut (Kerstigiella geocarpa Harms) landraces from northern Ghana
}

\author{
Bayorbor, T.B ${ }^{1}$., Dzomeku, I.K․, Avornyo, V.K ${ }^{1}$ and Opoku-Agyeman, M.O'2. \\ ${ }^{1}$ University for Development Studies, Faculty of Agriculture, Box TL 1882, Tamale, Ghana. \\ ${ }^{2}$ CSIR - Plant Genetic Resources Research Institute, P.O. Box 7, Bunso E/R Ghana \\ ABSTRACT
}

\begin{abstract}
Twelve landraces of kersting's groundnut (Kerstingiella geocarpa Harms), collected from northern Ghana in 2004 were evaluated for plant height, canopy spread, leaf area index, nodule count, days to $50 \%$ flowering, fresh and dry shoot weight, fresh and dry root weight, pod number per plant, grain yield and hundred seed weight. The following parameters were similar $(p>0.05)$ among the landraces: leaf area index, nodule count at 7 and 9 WAP, dry shoot weight at 7 WAP, fresh and dry shoot weight at 7 WAP, number of pods per plant and hundred seed weight. Plant height at 8 WAP significantly varied $(p=0.026)$ among the landraces. The landraces Boli, Heng milk mottled, Gbangu, Nakori and Puffeon produced the tallest plants. Canopy spread of Heng red mottled, Heng milk mottled, Boli, Nakori, Nankpaduri, Puffeon and Gbangu exceeded other entries at 9 WAP. Days to $50 \%$ flowering varied significantly $(p=0.001)$ among landraces with Puffeon, Gbangu, Heng milk mottled, Nakori and Heng red mottled flowering early. At 7 WAP, fresh shoot weight was significantly $(p=0.002)$ different among the landraces with Heng milk mottled, Funsi, Nankpaduri, Boli, Sigiri, Dugulatuk, and Gbangu outstanding. Grain yield was highly significant ( $p$ $=0.001$ ) with Heng red mottled, Funsi, Puffeon, and Sigiri as best yielders. Six Principal components (PC) were significantly informative in a factor analysis. The PC1 contained $90.76 \%$ of the total variation in the collection. A cluster analysis revealed that the measured traits accounted for only $12 \%$ of the variation with two major clusters.
\end{abstract}

\section{INTRODUCTION}

Kersting's groundnut, (Kerstingiella geocarpa Harms) also known as Macrotyloma geocarpum is the third subterranean legume (Marechal and Baudet, 1977). Kersting's groundnut belongs to the family leguminosae and the subdivision papilionoideae (Obasi and Ezedinma, 1991). The crop is indigenous to Africa and a promising alternative source of high quality protein for food and feed for the tropics (Duke et al., 1977; Obasi and Ezedinma, 1991 and Obasi and Agbatse, 1994). According to Smartt (1990) kersting's groundnut as grown in West Africa has consistently produced poor yields.

Currently, the only reported difference among kersting's groundnut accessions is seed colour. Duke et al., (1977) reported the existence of white, mottled and black seeds among the accessions. Traditionally, diversity within and between populations is determined by assessing differences in morphology. Morphological information have an important attribute of being available for immediate use, do not require sophisticated equipment and are the most direct measure of phenotype. However, such information needs to be taken by an expert in the species, since morphology is subject to changes by environmental factors and may vary at different developmental stages (de Vicente and Fulton, 2003).
Notwithstanding limitations of the use of morphological characterization such as, genotype $x$ environment interaction in the expression of the various traits, agromorphological studies of plants have no substitute in selection and breeding. They, at worst, are always a useful complement to the available advanced biotechnological tools. Ecologically vulnerable and research neglected species like Kersting's groundnut would be completely lost, together with associated cultural information, if simple and readily available techniques are not used to facilitate their diversity studies.

Morphological markers have been used to identify varietal genotype and genetic purity based on the assessment of phenotype characteristics. They have played important role in crop improvement since the beginning of modern breeding programme. Prior to the development of molecular markers, genetic characterization was mainly carried out using morphological characters (Patterson and Weathercup, 1984; Mignouna et al., 1996). Plant characters such as the growth habit, branching pattern, stem pigmentation and days to maturity have been widely used to characterize various cultivars and accessions of groundnuts (Singh and Simpson, 1994). In aroids for example, a number of varieties 
and even species have been identified based on morphological characters (Karikari, 1971; OpokuAgyeman et al., 2004). There is the urgent need for germplasm collection and characterization to bring to light the available gene pool to aid breeding. This work was therefore undertaken to assess morphological variation in a collection of Kersting's groundnut landraces from northern Ghana.

\section{MATERIALS AND METHODS}

The study was conducted at Nyankpala, near Tamale in the Northern Region of Ghana, which lies within the Guinea savanna agro-ecological zone. Nyankpala experiences unimodal rainfall pattern with an average of $1034.4 \mathrm{~mm}$ per annum. Temperature distribution is moderately uniform with a monthly mean minimum and maximum value of $23.4^{\circ} \mathrm{C}$ and $38^{\circ} \mathrm{C}$ respectively. The soil of the study area has been described as silty loam in texture, structureless and classified as Haplic Plinthosol (Kanoah, 2009).

Twelve Kersting's groundnut landraces were collected from the Northern and Upper West Regions of Ghana and evaluated in a randomized complete block design with three replications. The landraces were Nakori, Funsi, Dowie, Gbangu, Heng red mottled, Heng milk mottled, Sigiri, Najung, Dugulatuk, Puffeon, Boli and Nankpanduri. Data collected included plant height, canopy diameter, leaf area index (LAI), fresh shoot weigh (FSW), dry shoot weigh (DSW), fresh root weight (FRW), Dry root weight (DRW), nodulation, number of days to $50 \%$ flowering, grain yield and hundred seed weight. These quantitative traits were also used to study variability in a multivariate analysis in the 12 landraces of Kersting's groundnut. Factor analysis including principal components (PC) with output in a table and scatter plot was conducted using the Genstat (Version 9.2.0.152) software to understand the contributions of the various measured traits to the total variance. The traits that made the first principal components were used in a hierarchical cluster analysis with output in a dendrogram.

\section{RESULTS AND DISCUSSION}

Plant height, canopy diameter and Leaf area index (LAI): Plant height showed no significant ( $p>$ $0.05)$ difference among the landraces at 4 and 6 weeks after planting (WAP). However, at 8 WAP, plant height significantly varied $(p<0.05)$ among the landraces (Table 2). Boli, Heng milk mottled, Heng red mottled, Nakori, Gbangu and Puffeon, were taller than Dowie, Dugulatuk, Funsi, Najung and Nankpanduri. Canopy diameter followed the same pattern as plant height, showing no significant $(p>$
0.05) difference among landraces within the early stages of growth. At 9 WAP however, canopy diameter differed significantly $(p<0.028)$. Heng red mottled, Boli, Funsi, Heng milk mottled and Dugulatuk recorded the widest canopy diameter while Dowie recorded the lowest. The landraces with the widest canopy diameter might be exhibiting an inherent ability to utilize environmental factors favourably. Leaf area index was in the range of $2.0-$ 2.9 but showed no variation among landraces (Table 2).

Table 1. Visual colour classification of 12 kersting's groundnut landraces

\begin{tabular}{lll} 
Black & White & Mottled \\
\hline Najung & Boli & Nakori \\
Puffeun & Nakpanduri & Funsi \\
Dugulatuk & & Dowie \\
Gbangu & & Heng milk mottled \\
& & Heng red mottled \\
& & Sigiri
\end{tabular}

Table 2. Plant height, canopy diameter and leaf area index

\begin{tabular}{|c|c|c|c|}
\hline Landrace & $\begin{array}{l}\text { Mean } \\
\text { leaf } \\
\text { area } \\
\text { index }\end{array}$ & $\begin{array}{l}\text { Mean plant } \\
\text { height } 8 \\
\text { WAP }\end{array}$ & $\begin{array}{c}\text { Mean canopy } \\
\text { diameter }(\mathrm{cm}) 9 \\
\text { WAP }\end{array}$ \\
\hline Boli & 2.68 & $39.50 a$ & $51.43 a b$ \\
\hline Dowie & 2.49 & $34.27 \mathrm{bcd}$ & $46.07 \mathrm{~cd}$ \\
\hline Dugulatuk & 2.72 & $33.90 \mathrm{~cd}$ & 47.48abcd \\
\hline Funsi & 2.45 & $34.23 \mathrm{bcd}$ & 47.93abcd \\
\hline Gbangu & 2.32 & $35.70 a b c d$ & $46.53 \mathrm{bcd}$ \\
\hline Heng MM & 2.12 & $37.70 \mathrm{ab}$ & $51.40 \mathrm{ab}$ \\
\hline Heng RM & 2.46 & $36.47 \mathrm{abcd}$ & $52.15 a$ \\
\hline Najung & 2.61 & $33.67 d$ & $43.83 c$ \\
\hline Nakori & 2.90 & $37.20 \mathrm{abc}$ & $50.13 a b c$ \\
\hline Nakpanduri & 2.08 & 34.17bcd & 49.40abc \\
\hline Puffeun & 2.00 & 35.23abcd & $50.37 a b c$ \\
\hline Sigiri & 2.34 & $35.03 \mathrm{bcd}$ & 48.20abcd \\
\hline $\begin{array}{l}\text { Grand } \\
\text { mean }(\mathrm{cm})\end{array}$ & 2.43 & 35.59 & 48.83 \\
\hline C.V (\%) & 23.1 & 5.4 & 5.5 \\
\hline S.E.D. & 0.4596 & 1.573 & 2.188 \\
\hline
\end{tabular}

Means with identical letters in the same column are not significantly different at $5 \%$ significance level by Duncan's Multiple Range Test.

Fresh and Dry Shoot Weight (FSW \& DSW): At 7 WAP, fresh shoot weight was significantly $(p<0.05)$ different among the landraces. In contrast, DSW showed no significant variation. The mean FSW ranged from $123.9 \mathrm{~g}$ for Puffeon to $302.4 \mathrm{~g}$ for Heng milk mottled (Table 3). The opposite scenario was observed 9 WAP, where the FSW remained similar but DSW varied significantly $(p<0.05)$. The mean dry shoot weight at 9 WAP ranged from $32.2 \mathrm{~g}$ for Heng milk mottled to $76.1 \mathrm{~g}$ for Najung (Table 3). 
Generally, the landraces which recorded the highest FSW flowered earlier than other entries.

Number of nodules and pods per plant and days to $50 \%$ flowering: At 7 WAP and 9 WAP, the landraces evaluated did not show differences $(p>$ 0.05) in nodule count and pod formation (Table 4). Entries such as Puffeon and Gbangu appear to have high nodulation at 7 WAP whilst Boli and Dugulatuk gave an enhanced number at 9 WAP. The landraces might therefore have similar nitrogen fixing potentials. Days to $50 \%$ flowering was different $(p=0.001)$ among the landraces. The landraces took between 55 to 63 days to flower (Table 4). Those that flowered earlier were Gbangu, Puffeon, Nakori, Heng milk mottled and Heng red mottled.

Grain yield and hundred seed weight: The landraces were different $(p<0.001)$ in grain yield production. Five landraces, Funsi, Heng MM, Heng RM, Puffeon and Sigiri were the top yielders (1428 $1876 \mathrm{~kg} / \mathrm{ha}$ ), whilst four entries: Dugulatuk, Gbangu, Najung, and Nankpanduri (635 - 1067 kg/ha) performed poorly (Table 5). Some of the landraces with the widest canopy diameter also recorded the highest grain yield. These yields are higher than the $500 \mathrm{~kg} / \mathrm{ha}$ reported by Duke et al. (1977). These landraces might be translating their better photosynthetic potential to grain yield. Hundred seed weight was however not significantly affected by the different landraces.

Table 3. Fresh and dry shoot weight

\begin{tabular}{lll}
\hline Landrace & $\begin{array}{l}\text { Mean fresh shoot } \\
\text { weight } \\
\text { 7 WAP }\end{array}$ & $\begin{array}{l}\text { Mean dry shoot } \\
\text { weight } \\
\text { 9 WAP }\end{array}$ \\
\hline Boli & $291.0 \mathrm{ab}$ & $65.7 \mathrm{abc}$ \\
Dowie & $238.2 \mathrm{abc}$ & $61.1 \mathrm{abc}$ \\
Dugulatuk & $224.6 \mathrm{abcd}$ & $52.8 \mathrm{abcd}$ \\
Funsi & $269.0 \mathrm{ab}$ & $50.3 \mathrm{bcd}$ \\
Gbangu & $208.3 \mathrm{abcd}$ & $67.5 \mathrm{abc}$ \\
Heng MM & $302.4 \mathrm{a}$ & $71.7 \mathrm{ab}$ \\
Heng RM & $150.1 \mathrm{~cd}$ & $32.2 \mathrm{c}$ \\
Najung & $183.6 \mathrm{bcd}$ & $76.1 \mathrm{a}$ \\
Nakori & $182.4 \mathrm{bcd}$ & $33.1 \mathrm{c}$ \\
Nakpanduri & $282.2 \mathrm{ab}$ & $54.3 \mathrm{abcd}$ \\
Puffeun & $123.4 \mathrm{c}$ & $45.1 \mathrm{~cd}$ \\
Sigiri & $210.5 \mathrm{abcd}$ & $55.1 \mathrm{abc}$ \\
& & \\
\hline Grand mean (g) & 222.1 & 55.4 \\
C.V (\%) & 25.7 & 21.4 \\
S.E.D. & 46.58 & 9.69 \\
\hline Means with identical letters in the same column are not \\
significantly different at $5 \%$ significance level by Duncan's \\
Multiple Range Test.
\end{tabular}

Table 4. Nodule count and days to $50 \%$ flowering

\begin{tabular}{llll}
\hline Landrace & $\begin{array}{c}\text { Mean of } \\
\text { nodule } \\
\text { count 7 } \\
\text { WAP }\end{array}$ & $\begin{array}{c}\text { Mean of } \\
\text { nodule count } \\
\text { 9 WAP }\end{array}$ & $\begin{array}{l}\text { Mean days } \\
\text { to 50\% } \\
\text { flowering }\end{array}$ \\
\hline Boli & 20.93 & 32.5 & $9.00 \mathrm{cde}$ \\
Dowie & 19.93 & 15.7 & $58.00 \mathrm{e}$ \\
Dugulatuk & 20.23 & 24.7 & $55.67 \mathrm{f}$ \\
Funsi & 20.27 & 15.7 & $58.67 \mathrm{cde}$ \\
Gbangu & 23.67 & 23.3 & $63.33 \mathrm{a}$ \\
Heng MM & 15.33 & 21.0 & $61.67 \mathrm{ab}$ \\
Heng RM & 22.73 & 2.3 & $61.00 \mathrm{adc}$ \\
Najung & 16.20 & 18.8 & $60.33 \mathrm{bcde}$ \\
Nakori & 18.33 & 24.5 & $62.67 \mathrm{ab}$ \\
Nakpanduri & 10.33 & 16.5 & $58.33 \mathrm{de}$ \\
Puffeun & 23.80 & 12.8 & $63.33 \mathrm{a}$ \\
Sigiri & 17.00 & 21.2 & $60.67 \mathrm{bcd}$ \\
& & & \\
\hline Grand mean & 19.07 & 21.1 & 60.22 \\
C.V (\%) & 25.3 & 53.2 & 2.1 \\
S.E.D. & 3.937 & 9.17 & 1.029
\end{tabular}

Means with identical letters in the same column are not significantly different at $5 \%$ significance level by Duncan's Multiple Range Test

Table 5. Grain yield and 100 seed weight.

\begin{tabular}{lll}
\hline Landrace & $\begin{array}{l}\text { Mean grain yield } \\
\text { (kg/ha) }\end{array}$ & $\begin{array}{l}\text { Mean } \mathbf{1 0 0} \\
\text { weight } \mathbf{( g )}\end{array}$ \\
\hline Boli & $1141 \mathrm{cdef}$ & 15.09 \\
Dowie & $1387 \mathrm{bcd}$ & 17.40 \\
Dugulatuk & $778 \mathrm{fg}$ & 16.09 \\
Funsi & $1603 \mathrm{ab}$ & 16.72 \\
Gbangu & $966 \mathrm{efg}$ & 15.96 \\
Heng MM & $1876 \mathrm{a}$ & 17.57 \\
Heng RM & $1701 \mathrm{ab}$ & 16.60 \\
Najung & $1027 \mathrm{defg}$ & 16.79 \\
Nakori & $1325 \mathrm{bcde}$ & 17.37 \\
Nakpanduri & $635 \mathrm{~g}$ & 17.41 \\
Puffeun & $1468 \mathrm{abc}$ & 17.97 \\
Sigiri & $1529 \mathrm{abc}$ & 16.70 \\
& & \\
\hline Grand mean & 1286 & 16.81 \\
C.V (\%) & 17.0 & 6.4 \\
S.E.D. & 178.7 & 0.874 \\
\hline
\end{tabular}

Means with identical letters in the same column are not significantly different at $5 \%$ significance level by Duncan's Multiple Range Test.

Cluster analysis: A scree plot drawn from the results of a factor analysis of twenty six morphological traits revealed six factors as having eigen values of more than one (eigen val.>1), Figure 1. This indicated that six PCs could be selected as the appropriate number of factors that most approximate the total variance in the measured traits. The first principal component, out of a total of six extracted components, had $90.76 \%$ of the total variance. The scatter plot of the six PCs revealed the factors of the first principal component in a more organized enclosed spatial 
distribution (Figure 2). Components score coefficients were $1.13,0.78,0.72,-0.10,-0.16$ and 1.12 for PC1 through PC 6 respectively.

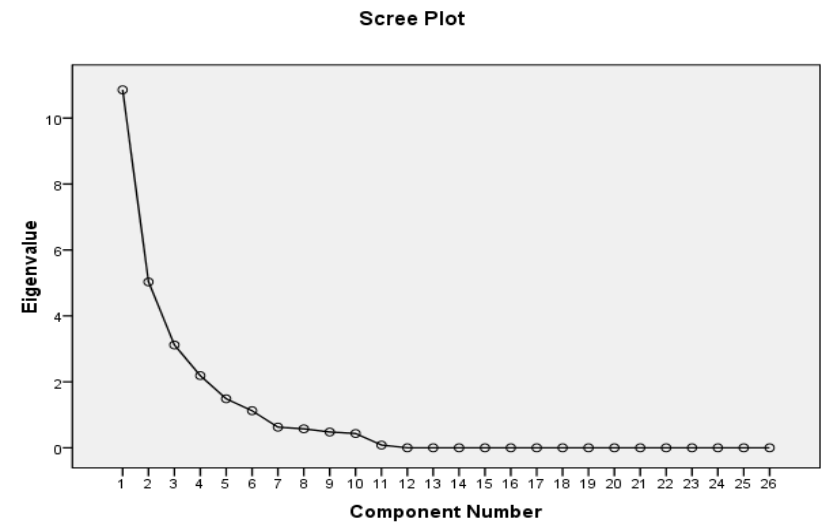

Fig 1. Scree plot of 26 quantitative traits of Kesting's groundnut from the northern region of Ghana

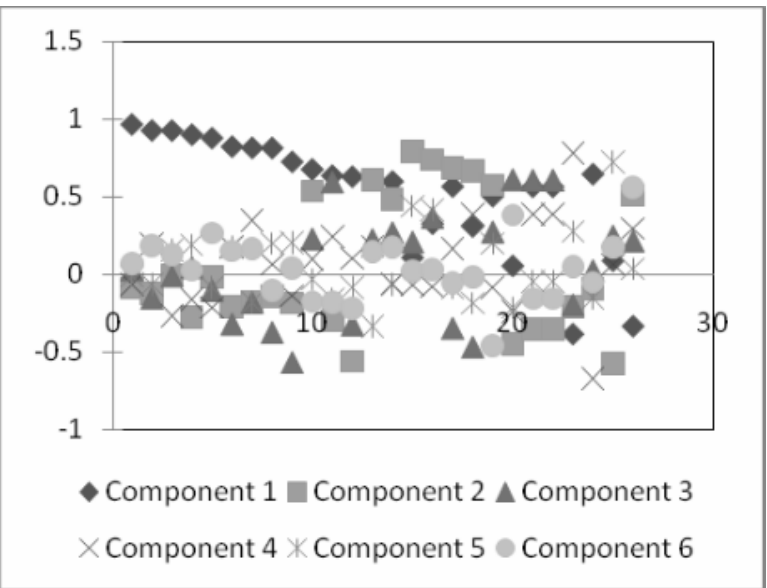

Fig 2. Spatial distribution of 26 quantitative traits of Kesting's groundnuts

The first $P C$ traits with significant pairwise correlation values ( $R>0.5$ ) were PLANT HEIGHT at 6 WAP, 5 WAP, 7WAP, 8 WAP, CANOPY DIAMETER AT 5 WAP, 6 WAP, PLANT HEIGHT at 4 WAP, CANOPY DIAMETER at 7 WAP, 8 WAP, DRW at 9 WAP, PODS/PLT, CANOPY D 9 WAP, FRW 7WAP and DRW 7 WAP (Table 6). These are mainly factors of plant architecture (shoot and roots) and yield components. Knowledge of the traits that vary in a population is vital information on which breeding decisions are based (Skroch et al., 1998; Witcombe et al., 2001).

The Kestings groundnut landraces under this study were not very diverse. They share approximately $88 \%$ similarity at which point two major clusters are observed (Figure 3). The smaller of the two main clusters has two landraces (Heng MM and Boli) that are $94.5 \%$ similar. The relative differences in the total collection could be explained in just $12 \%$ dissimilarity. The two most similar landraces in the entire collection were Heng RM and Nakori. They shared 97\% similarity. They were followed closely by the pair Dugulatuk and Puffeon with $96.5 \%$ similarity. The last two similar pairs belong to the larger cluster that share $92 \%$ similarity. The landraces, named after their respective specific locations of collection, were gathered from the Northern and Upper West regions of Ghana, a probable reason why they have very little variability. Heng RM and Heng MM originated from the same locality but were differentiated by the mottling pattern, and separated by a distance of 0.15 . Both landraces were noted for early flowering, higher grain yields and wider canopy spread but Heng MM was taller than Heng RM at 8 WAP. Besides Heng $\mathrm{MM}$ and Boli that clustered uniquely, all other landraces noted for significantly higher heights were found in the bigger second cluster with variable similarity coefficients.

The Kersting's groundnut collection under study was collected from farmers. The low variability observed could be attributed to the mode of seed distribution in Ghanaian communities. Seeds of crops that have not become high income generating cash crops are mostly distributed freely from one farmer to the neighbour. One cultivar that has an attractive attribute could spread very far relegating other genetically important relatives into oblivion. BennettLartey et al., (2002) and Quiroz et al., (2002) observed similar patterns in the distribution and gene flow of seeds in their studies on home gardens and farming systems in Ghana and Venezuela respectively. 


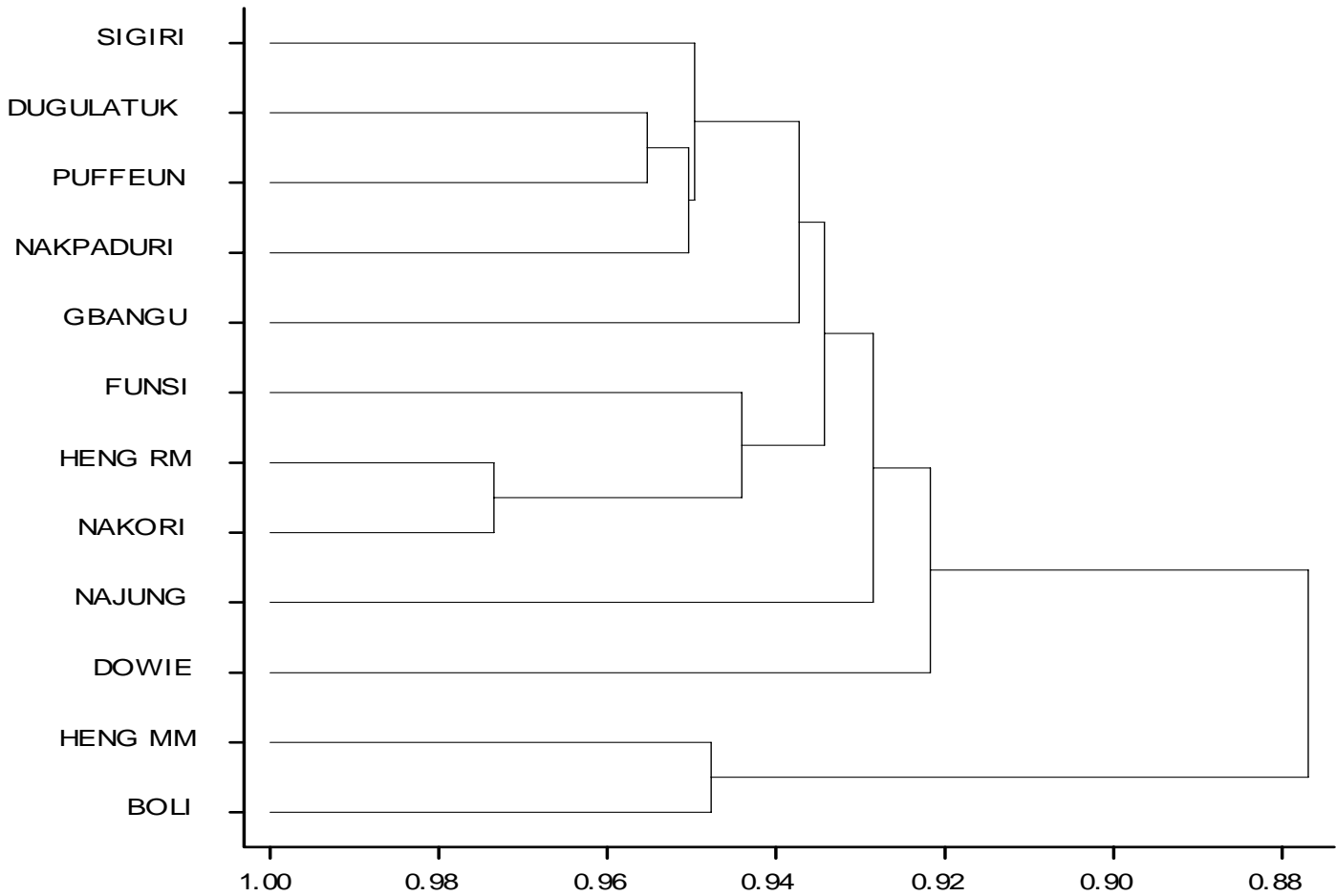

Fig 3. UPGMA dendrogram (Average linkage) of 12 landraces of Kestings groundnut from the northern region of Ghana (Coefficient: Euclidian)

Table 7. Similarity matrix (Coefficient Euclidean) of twelve Kesting's groundnuts landraces

\begin{tabular}{|c|c|c|c|c|c|c|c|c|c|c|c|c|}
\hline & SIGIRI & $\begin{array}{l}\text { NAJU } \\
\text { NG }\end{array}$ & $\begin{array}{l}\text { GBAN } \\
\text { GU }\end{array}$ & $\begin{array}{l}\text { NAKPANDU } \\
\text { RI }\end{array}$ & $\begin{array}{l}\text { PUFF } \\
\text { EUN }\end{array}$ & $\begin{array}{l}\text { HEN } \\
\text { G } \\
\text { MM }\end{array}$ & $\begin{array}{l}\text { DOW } \\
\text { IE }\end{array}$ & $\begin{array}{l}\text { HEN } \\
\text { G } \\
\text { RM }\end{array}$ & $\begin{array}{l}\text { FUN } \\
\text { SI }\end{array}$ & $\begin{array}{l}\text { DUGULA } \\
\text { TUK }\end{array}$ & $\begin{array}{l}\text { NAKO } \\
\text { RI }\end{array}$ & BOLI \\
\hline SIGIRI & 1.000 & & & & & & & & & & & \\
\hline NAJUNG & 0.896 & 1.000 & & & & & & & & & & \\
\hline GBANGU & 0.899 & 0.861 & 1.000 & & & & & & & & & \\
\hline NAKPADURI & 0.809 & 0.829 & 0.872 & 1.000 & & & & & & & & \\
\hline PUFFEUN & 0.859 & 0.867 & 0.874 & 0.835 & 1.000 & & & & & & & \\
\hline HENG MM & 0.755 & 0.550 & 0.763 & 0.638 & 0.638 & 1.000 & & & & & & \\
\hline DOWIE & 0.917 & 0.888 & 0.897 & 0.813 & 0.828 & 0.727 & 1.000 & & & & & \\
\hline HENG RM & 0.845 & 0.728 & 0.890 & 0.775 & 0.904 & 0.802 & 0.812 & 1.000 & & & & \\
\hline FUNSI & 0.902 & 0.837 & 0.905 & 0.787 & 0.907 & 0.823 & 0.917 & 0.934 & 1.000 & & & \\
\hline DUGULATUK & 0.917 & 0.921 & 0.936 & 0.920 & 0.918 & 0.694 & 0.901 & 0.872 & 0.895 & 1.000 & & \\
\hline NAKORI & 0.835 & 0.728 & 0.909 & 0.834 & 0.861 & 0.839 & 0.809 & 0.971 & 0.917 & 0.878 & 1.000 & \\
\hline BOLI & 0.689 & 0.445 & 0.736 & 0.523 & 0.507 & 0.933 & 0.677 & 0.758 & 0.723 & 0.624 & 0.794 & 1.000 \\
\hline
\end{tabular}




\section{REFERENCES}

Bennett-lartey S.O., Ayenor, G.S., Markwei, C.M., Asante I.K., Abbiw, D.K., Boateng S.K., Anchirinah, V.M. and Ekpe, P. (2002). Contribution of home gardens to to in situ conservation of plant genetic resources in farming systems in Ghana. In: Watson, J. W. and P.B Eyzaguirre. Proceedings of the Second International Home Gardens Workshop: Contributions of home gardens to in situ conservation of plant genetic resources in farming systems, 17-19 July 2001, Witzenhausen, Federal Republic of Germany. International Plant Genetic Resources Institute, Rome.

De Vicente, C., Fulton, T. (2003). Molecular Marker Learning Modules - Vol. 1. IPGRI, Rome, Italy and Institute for Genetic Diversity, Ithaca, New York, USA. (http://www.bioversityinternational.org/Publications/Mo lecular Markers Volume 1 en/index.asp)

Duke, J.A., Okigbo, B.N. and Reed, C.F. (1977). Underexploited legumes; kersting's groundnuts (Macrotyloma geocarpum Harms; Marechal and Baudet). Tropical Grain Legumes Bulletin, 31:39-44.

Karikari S.K. (1971). Cocoyam Cultivation in Ghana. World Crops 23:118-122.

Kanoah, A.K. (2009). Characterization and classification of the Nyankpala series according to Soil Taxonomy and the World Reference Base of Soil Resources (WRB). Unpublished B.Sc Dissertation. Department of Agronomy. University for Development Studies. Tamale - Ghana.

Marechal, R. and Baudet, J.C. (1977). Transfert du genre Africain Kerstingiella Harms a Macrotyloma (Wight and Arn) Verdc. (Papilionaceae). Bull. Jard. Bot. Nat. Belg. 47:49-52

Mignouna, H.D., Fatokun, C.A. and Thottapilly, G. (1996). Choice of DNA Markers. In: DNA Marker Assisted Improvement of Staple Crop of Sub-Saharan Africa, Proceedings and Workshop on DNA Markers. (Eds. J.H Crouch and A. Tenkouano) IITA. Ibadan, Nigeria 21-22 August 1996. Pp 9-15.

Obasi, M.O. and Ezedinma, F.O.C. (1991). Evaluation of the growth and chemical composition of Kersting's groundnuts. Indian Journal of Agric. Sci. 61 (11): 811814.

Obasi, M.O. and Agbatse, A. (1994). Evaluation of nutritive value and some functional

properties of kersting's groundnut, (Kerstingiella geocarpa Harms). Seeds for optimal utilization as food and feed source. East African Agricultural Journal. 54:6674

Opoku-Agyeman, M.O., Benett-Lartey, S.O. and Markwei, C. (2004). Agro-morphological and sensory characterization of cocoyam (Xanthosoma sagittifolium (L) (Schott) germplasm in Ghana. Ghana Journal of Agriculture Science. 37: 23-31

Patterson, H.D. and Weathercup. S.T.C. (1984). Statistical criteria for distinctness between varieties of herbage crops. Journal of Agriculture Science 102: 59-68.

Quiroz C., Gutierrez, M., Rodrigues, D., Perez, D., Ynfante, J., Gomez, J., Perez de Fernandez, T., Marques A., and Pacheco, W. (2002). Home gardens and in situ conservation of agrobiodiversity - Venezuelan Component. In: Watson, J. W. and P.B Eyzaguirre. Proceedings of the Second International Home Gardens Workshop: Contributions of home gardens to in situ conservation of plant genetic resources in farming systems, 17-19 July 2001, Witzenhausen, Federal Republic of Germany. International Plant Genetic Resources Institute, Rome.

Skroch, P.W., Nienhuis, J., Beebe S., Tohme, J. and Pedraza, F. (1998). Comparison of Mexican common bean (Phaseolus vulgaris L.) core and reserve germplasm collections. Crop Sci. 38: 488-496.

Singh, A.K. and Simpson, C.E. (1994). Biosystematics and genetic resources. In: The Groundnut Crop: Scientific Bases for Improvement. (Ed. J. Smart),. Chapman and Hall, London. pp 96-133

Smart, J. (1990). Grain Legumes: Evolution and Genetic Resources. Cambridge university press. pp $299-301$.

Witcombe, J.C.R., Joshi, K.D., Rana, R. B., Vick, D.S. (2001). Increasing Genetic Diversity by Participatory Variety Selection In High Potential Producation Systems In Nepal And India. Euphytic. 122: 575-588. 